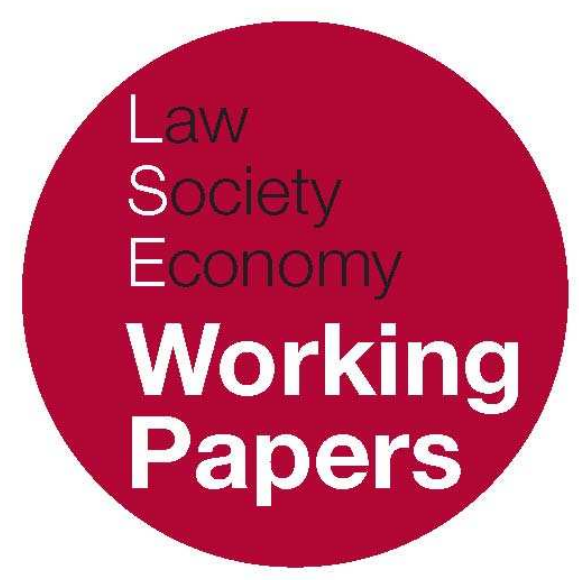

\title{
Arbitration in Three Dimensions
}

\author{
Jan Paulsson \\ LSE Law, Society and Economy Working Papers 2/2010 \\ London School of Economics and Political Science \\ Law Department
}

This paper can be downloaded without charge from LSE Law, Society and Economy Working Papers at: www.lse.ac.uk/collections/law/wps/wps.htm and the Social Sciences Research Network electronic library at: http://ssrn.com/abstract $=1536093$.

(C) Jan Paulsson. Users may download and/or print one copy to facilitate their private study or for non-commercial research. Users may not engage in further distribution of this material or use it for any profit-making activities or any other form of commercial gain. 


\title{
Arbitration in Three Dimensions
}

\author{
Jan Paulsson *
}

\begin{abstract}
The law applicable to arbitration is different from the law applicable in arbitration. The latter leads arbitrators to decide as they do. The former refers to the source of their authority and the effect of their decision - the legal order that governs arbitration. According to the territorialist thesis, an arbitration can have no foundation other than that of the legal order of the particular state where the arbitration takes place. This outdated conception is disproved by the simple factual observation that a plurality of legal orders may give effect to arbitration. Some French scholars promote the notion of an autonomous arbitral order. Inasmuch as they ultimately seek to establish this order by positing its recognition by the very state orders from which they claim autonomy, their idea is circular and in effect no more than a dressed-up variant of ordinary horizontal pluralism. But the model of horizontal pluralism fails to account for important orderings of arbitral activity. Arbitration in modern society is accurately perceived as a complex, three-dimensional form of pluralism, in which legal orders (i) are not exclusively those of states and (ii) frequently overlap.
\end{abstract}

\section{INTRODUCTION}

Lectures on legal theory tend to have two things in common. First, the speaker is convinced of the transcendent importance of the subject, holding forth ardently to the point of losing track of time. Secondly, the audience is less likely to perceive that they are being treated to earthshaking revelations, which after all present

\footnotetext{
* Law Department, London School of Economics and Political Science. Centennial Professor, London School of Economics; Michael Klein Distinguished Chair, University of Miami. This is the text of Professor Paulsson's inaugural lecture as Centennial Professor at the LSE, delivered 24 November 2009.
} 
themselves only once in a blue moon. So they are restless, likely to daydream and long for release. Nevertheless I will try my luck. In raising some theoretical matters relating to arbitration, I hope that it is not too much to ask of an English audience that they for once sample this unfamiliar fare. One might name a dozen theoretical works written in French off the top of one's head. The Englishspeaking world, on the other hand, has the benefit of splendid writings that make sense of statutes and rules and cases dealing with arbitration, immensely valuable treatises on the craft of arbitration, but I can think of no book-length work on its theory. Technical rules and solutions come and go, as fashions change and practice evolves. The usefulness of knowledge does not endure; it is ever incomplete without some insight into the nature and objectives of our enterprise. Ideas move the world, not knowhow. This evening I propose to examine two clusters of ideas.

First, what is the legal ordering that gives effect to the social institution we call arbitration? What is it that makes arbitration lawful and awards binding? Since this is a lecture and not a debate, I can choose my adversaries in order to do battle in comfort. On the one extreme, we have what I will call the dogmatic territorialism of Francis Mann; on the other, what I will call Parisian poetry. You will understand that I wish to lead you into the safety and soundness of middle ground. Here is what you should conclude: arbitration derives its legitimacy and its effectiveness from an unknown number of potentially relevant legal orders.

The second objective of my remarks will be to explore this pluralistic world in which modern arbitration thrives. I will not ask you to approve it, but merely to acknowledge that it exists, that it is ascendant, and that the varied combinations of legal orders in which it operates are not limited to those of the law of states - with the result that they may overlap. The reality of modern arbitration, in other words, is three-dimensional.

\section{MATTERS OF DEFINITION}

The great paradox of arbitration is that it seeks the cooperation of the very public authorities from which it wants to free itself. The law of arbitration', as traditionally conceived, is the manifestation of this tension. What will the state tolerate? To what will it lend its authority and power? Are arbitrations by necessity legally connected to a particular jurisdiction? If so, is it correct to say that only the law of that jurisdiction may give effect to awards? Can arbitration function without the support of the law of a particular state? These questions become more tangible when they arise in an international context. As communities in the world integrate, and as the once exclusive orderings of states disintegrate, these inquiries become not only more interesting, but indispensable. 
Our questions may be examined by reference to four more or less competing propositions. The first is that any arbitration is perforce national and lives or dies according to the law of the place of arbitration. This might be called the territorial thesis. The second is that arbitration may be given effect by more than one legal order, none of them inevitably essential. This is the pluralistic thesis. The third proposition is that arbitration is the product of an autonomous legal order accepted as such by arbitrators and judges. The fourth proposition is that arbitration may be fully effective pursuant to conventional arrangements that do not depend on national law or judges at all. Whether such arrangements may qualify as legal orderings may be debated. My answer is affirmative, and so this fourth proposition ultimately merges with the second: it accounts for an important feature of pluralism in the ascendancy.

A critical examination of these abstract propositions helps us understand the concrete stuff of lawyers' daily work. Consider the position of a fictional Maitre Dupont, appointed by a Swiss chamber of commerce to decide a dispute between two Swiss parties who do not even own passports. What would Maitre Dupont conclude if she sought to identify the legal foundation for her authority?

She might start with this reasonable working hypothesis: She expects that she will receive evidence and written submissions; will hear from parties, witnesses, and lawyers; will evaluate contentions put to her with respect to alleged breaches of contract; and will finally prepare and render an award which upholds or rejects claims. She assumes that the parties, like it or not, will comply with her decision. Such is the usual narrative of an arbitration.

This sequence of events, she may reflect, seems to be a very juridical process, yet has very little to do with the authority of the Swiss Confederation. She is not a public official and was not even appointed by a public official. At no point, from beginning to end, were any public officials involved or even informed. Every theoretical question leads to another: Is any legal foundation for her authority required beyond that of the parties' agreement? Is there a legal order that determines the nature and effects of arbitration? What is, in particular, the source of the right and duty to arbitrate, of the authority of the arbitrator, or of the effectiveness of awards? Must that source be a specific national legal order?

The prospect of taking the full step to the first principle - the definition of a legal order - is not certain to make any audience rejoice. After all, this is a domain to which swarms of exceptionally erudite and disputatious scholars have devoted pages as countless as the stars, destined to be read, it seems, chiefly by others intending to add to the production. Perhaps it is possible to keep it simple and practical.

Many individuals may think themselves happy to live very far from 'the law' and its travails. This is wrong, because we are so often affected by law - but in implicit and episodic ways. For example, when the most unadventurous Swiss person sends a cheque to a French manufacturer in advance payment for some goods, whether he knows it or not, he is relying more on the French legal order than on the Swiss - for example, to know, in the event of the manufacturer's 
bankruptcy, whether he is the owner of goods in the warehouse or just a creditor at risk.

To return to Maitre Dupont: are she and her arbitration part and parcel of the Swiss legal order because Swiss courts would have the power to enforce her award if it satisfied certain Swiss norms or to annul it if it did not? We want to answer 'yes'. The immanent presence of the Swiss legal system - its norms, its institutions, its culture - doubtless helps explain why the participants in Maitre Dupont's particular case behave as they do. So 'yes' is not wrong. Yet it is not enough. This is what we will discover as we study the first proposition and its deficiencies.

\section{THE TERRITORIAL THESIS}

Our planet is divided into plots, each attributed to a jealous state. What happens within that plot can have no legal significance if it is not given that effect by those who exercise power in the name of the state holding dominion there. Every event must be localised within one of these plots. To give legal effect to events occurring inside the plot by reference to external norms is aberrant as a matter of political philosophy, and nonsense as a matter of law. This is the territorial thesis. It is outdated, but its influence lingers.

It has become part of Francis Mann's legacy to be identified as the inflexible proponent of the territorialist thesis. This reputation is built on these two oftquoted passages from an essay he published in 1967 under the title 'Lex Facit Arbitrum':

Just as, notwithstanding its notoriously misleading name, every system of private international law is a system of national law, every arbitration is a national arbitration, that is to say, subject to a specific system of national law. ${ }^{1}$

The lex arbitri cannot be the law of any country other than that of the arbitration tribunal's seat. No act of the parties can have any legal effect except as the result of the sanction given to it by a legal system. Hence, it is unavoidable to ascertain such system before the act of the parties can be upheld. When we say in the conflict of laws: 'contracts are governed by the law chosen by the parties,' we do so, and can do so, only by reason of the fact that the rule is part of the law of a specific legal system. ${ }^{2}$

1 In P. Sanders (ed), International Arbitration: Liber Amicorum for Martin Domke (Hague: Nijhoff, 1967), 159.

2 ibid, 161. 
On a subject of this importance, it should be unacceptable to treat these brief passages as a locus classicus. The focus of Mann's article, it is important to observe, was the law to be applied by arbitrators - not the legal foundations of arbitration. It was a sustained attack on those who argued for the freedom of arbitrators to base their decisions on perceptions of equity or of supranational norms. A central tenet of the article is that arbitrators must obey the private international law of the seat of arbitration: 'Any other solution would involve the conclusion that it is open to the arbitrator to disregard the law.' 3 Mann insisted that the only kind of law that could govern transactions involving non-states was the law of a given national state. He may well have been seeking to protect arbitrators from taking what he perceived as excessive license, leading to perceptions that arbitration is a tool for law-voidance in conflict with the public interest. Be that as it may, the article makes no distinction between identifying the law followed in making an award, on the one hand, and, on the other, the law that gives effect to the undertaking to arbitrate, to the arbitral process, and to the award. This confusion means that the passages quoted above are incidental assertions having uncertain connections with Mann's core analysis. To offer such generalisations seriously, one must perforce position oneself somewhere in the universe of legal theory. But Mann gave us nothing of the sort - only affirmation.

Reflecting on the two passages, one observes a false comparison in each. In the first, 'every system' of private international law is compared to 'every arbitration'. To be logical, Mann should have made a choice. On the one hand, he could have compared 'every system of private international law' to 'every system of arbitration law' and thus affirmed both to be specific systems of national law - not a very interesting idea. To the contrary, if his aim was to find a comparison for 'every arbitration', it ought to have been 'every matter that arises under private international law', leading to the proposition that both are 'subject to a specific system of national law' - and if the learned author had thus put the question accurately, he should readily have noticed that he was wrong. Problems arising under private international law are characteristically subject to a multiplicity of systems, and so it is with many arbitrations.

In the second passage, 'acts of the parties' are compared to stipulations of applicable law, to the effect that in each case they are given effect only by operation of 'a specific legal system'. Mann's thesis was that parties can choose only a single national law as the governing law of a contract. Whatever one may think of this notion (a very different subject), it obviously does not mean that 'acts of parties' may not be given effects - the same, or different - by more than one national legal system.

Refinements of the territorial thesis have emerged on both sides of the English Channel, broadly insisting that arbitrators are bound to deem the 'law of the arbitration' to be that of the place of arbitration, stressing that this still leaves

3 ibid, 167. 
parties considerable freedom - namely to select the legal order that will govern their activity by choosing the place of arbitration. ${ }^{4}$

This is one theory among others. No matter how 'realistic' its proponents claim to be, they cannot anchor it in positive law. In essence, they argue that predictability would be enhanced if it were universally accepted that arbitration has no greater or lesser effect than that given by the law of the place of arbitration. True, many enforcement jurisdictions may act on the basis that they will have no truck with an award shown to have no legal effect in the place where it was rendered. But as a matter of policy, surely it is curious to insist on the authority of a preordained lex arbitri, all the while observing that it is not preordained at all, since the parties may choose their legal order.

Nor is consistency ensured by imposing the hypothetical will of the legislator of the place of arbitration. This would make sense if there were only two possibilities, and the law of the place of arbitration was exalted over the law of the enforcement forum. But who knows how many conceivable enforcement fora may present themselves as promising? Nor are the possibilities exhausted there. There are also courts asked to decide a dispute notwithstanding the presence of an arbitration clause, or to grant provisional measures in aid of arbitration. Such courts may be situated in yet other countries. Surely, the attitudes toward arbitration of their legal orders are highly relevant to the efficacy of the mechanism. There is no assurance that all enforcement jurisdictions ultimately approached will politely agree among themselves when analysing the implications of what happened in the place of arbitration. (For example, whether a foreign award is illegitimate because the losing party was deprived of a reasonable opportunity to present its case, and that this was likely to have a material effect on the outcome, depends on the eye of the beholder and the narrative skills of counsel.) The theory does not moreover sit well with the observations that national jurisdictions may - as Switzerland does - enable parties to opt out of any judicial review of awards involving only foreigners, or more fundamentally, that the New York Convention on the Recognition and Enforcement of Foreign Arbitral Awards mandates enforcement without any need for the slightest expression of approval from the courts of the place of arbitration. And finally, who would seriously argue that an award set aside in country $\mathrm{X}$ because it was rendered by a female or irreligious arbitrator should be rejected by the courts of country $\mathrm{Y}$, making the judges of the latter complicit in a violation of international public policy?

4 See, eg, J.F. Poudret and S. Besson, Droit Comparé de l'Arbitrage International (Brussels: Bruylant, 2002), published in English as Comparative Law of International Arbitration (London: Sweet \& Maxwell, 2007), a book which in many ways could be deemed the Francophone antidote to the French doctrine as presented by E. Gaillard, Aspects Philosophiques du Droit de l'Arbitrage International (Leiden: Nijhoff, 2008); and R. Goode, 'The Role of the Lex Loci Arbitri in International Commercial Arbitration' (2001) 17 Arbitration International, 19. 
One can understand the territorialist model as a product of attitudes prevalent until the middle of the 20 $0^{\text {th }}$ Century. It simply does not fit the realities of an international society no longer constrained within national units - a world, moreover, in which national legal systems understand this new flux. If one looks again at Switzerland, the law there allows foreign parties to stipulate that there may be no recourse against awards. (That few avail themselves of this option does not make it less valid as an example.) So even if the losing party contends that the arbitral tribunal violated its right to be heard, it would not have the right to seek to have the award set aside by the Swiss courts. This serious alleged defect would naturally be subject to the control of courts asked to enforce the award. But then we instantly see that Mann's famous sentences are wrong. If the courts of another country examine the award and find it eligible for enforcement, it cannot possibly be said that this is so because the award finds its foundation in Swiss law. The point is driven home when one considers that a third country would be fully entitled to take a different view and declare that the award was obtained through a defective process. Once more, the Swiss position would be hypothetical - and irrelevant. Surely the word pluralism is apposite.

\section{THE PLURALISTIC THESIS}

Arbitration is not the rejection of law; it depends on law. True, it reproves much of law, especially the apparatus, and claims a special place in the law; but that is an application for advanced membership, not apostasy. Commentators have debated the necessity for arbitration to be a part of a particular national order. Some have followed Mann, insisting that nothing that purports to have occurred in the 'place' of arbitration, which may refer to the venue of hearings, the city where an award is signed or delivered, or the pure fiction of a deemed judicial 'seat' may have any legal significance unless that meaning is attributed to it by the legal system there. Others contend that the forces of internationalisation have now given birth to awards which do not owe their life to the law of the place of arbitration.

Courts have been influenced by this debate, unfortunately in divergent ways. On the one hand, for example, the French Cour de cassation has repeatedly asserted that an award rendered 'en matière internationale' is not 'integrated' into the legal order of the state where it was issued and may therefore be apprehended like wildfowl by the forum where it happens to alight. On the other, a number of US federal courts of appeal have invented a distinction of 'primary/secondary' jurisdictions in terms of controlling awards, and assigned the 'primary' appellation to the country where awards are rendered. These US courts have stated that this is their understanding of the New York Convention, which in fact nowhere mentions these terms. It is very difficult to see why their use is helpful, let alone necessary. States where enforcement may be sought have a far more tangible 
interest in the matter than the putative 'primary' jurisdiction which is often either chosen fortuitously or precisely because of its lack of connection with the dispute.

The matter is of considerable practical importance and therefore needs to be examined and resolved. Consider the case of an arbitration taking place in country A. An award is rendered there. Assume the courts of that country reserve the power to overrule an arbitral tribunal if they find a simple error of law and that there is thus a possibility of appeal. Most countries' judicial systems, whether by the operation of multilateral conventions or by unilaterally applied principles of comity, are prepared to enforce a foreign arbitral award only if satisfied that the award is 'binding'. The law of A will naturally have rules to determine whether an award rendered in A is binding. That law may hold an award not to be binding until it has resisted appeal (or unless no appeal has been lodged within a certain period). Yet nothing would prevent country B from legislating - and acting upon - a rule that an award by an arbitral tribunal constituted according to contractual agreement, wherever rendered, is binding for the purpose of enforcement in B at the moment it is pronounced.

So-called 'delocalised awards' are not thought to be independent of any legal order. The expression refers to the fact that an award may be accepted by the legal order of an enforcement jurisdiction whether or not the legal order of its country of origin has also embraced it. 'Plurilocalisation' would have been more accurate. This is no stranger than, say, the analysis of a contract signed in Munich by a Japanese consortium and an American contractor pertaining to engineering services in the Middle East. Legal consequences may flow from this contract because of the importance attributed to it by the legal orders represented by municipal courts in San Francisco, Tokyo, Alexandria, or elsewhere, depending on a multitude of potentially relevant jurisdictional criteria. Whether the contract failed to respect unusual German requirements of form is unlikely to matter. Noone is seriously likely to complain that the birth of the legal obligation in Munich airport was impermissibly miraculous because it sprang from the brow of the parties and was thus 'independent' of the German legal order.

Nor is there anything surprising about the fact that the same set of facts lead the legal system of one country, but not another, to conclude that an obligation has been created. It would be perhaps simpler, more convenient, more harmonious, if the law were the same everywhere. But we do not live in a monolithic world. This is also true with respect to obligations resulting from arbitral activity. In our example, the courts of country A might in the end conclude that the award is of no legal consequence; yet in country $\mathrm{B}$, the award is enforced. Legal orders are national, and they are different; they may assign different outcomes to the same event.

As long as the effects of arbitration were limited to a single national context, it may have seemed pointless to question the obvious: when both arbitrants are English, when the dispute concerns a contract drafted in the English language and governed by English law, when the tribunal is comprised entirely of English 
arbitrators sitting in London, and when the economic consequences depend on the fate of financial instruments domiciled in London banks - what other legal order but that of England could define the nature and consequences of the process? This misconceived rhetorical question is certainly understandable, and as a practical matter was unlikely to lead lawyers to error.

As the number of trans-border arbitrations grew exponentially over the past half-century, it became unavoidable that a number of national legal orders could have an impact. To take stock of this development, however, and to perceive the conceptual shift it commanded, took time.

First, international arbitrations throughout the 19th Century, and well into the $20^{\text {th }}$, were conducted pursuant to treaties. Their legal order was perforce that of public international law. The underlying disputes were occasionally commercial in origin, but the claims were made by states, on behalf of their nationals, against other states. There is, at least conceptually, only one over-arching international legal order.

Secondly, the environment of international private commercial relations bore little relation to today's world. The number of sovereign states formally qualified to establish national legal orders was only a fraction of what it is today. International commerce was of a far lesser macroeconomic magnitude. It tended to involve simple, short-term transactions. And of course, much overseas trade was of an intra-imperial nature, with the effect that disputes were subject to the metropolitan legal order, be it English or Dutch, Portuguese or Soviet. Arbitrations that might have appeared international due to the participation of exotic arbitrants were in fact not very international at all.

This situation did not leave much room for truly international commercial arbitration. A commercial dispute between French and German parties very likely involved one or the other physically carrying out its business in the country of its counterpart. It therefore made sense to go to court there. (Today negotiators of international contracts need not leave their desks and may be entering into variants of the same contract in a great number of countries.) And to the extent that there were international agreements to arbitrate, the resulting awards were in fact treated elsewhere - if at all - as pronouncements of the legal system of the country where they took place.

No better illustration can be given than to consider that when the Geneva Convention on the Execution of Foreign Arbitral Awards was concluded in 1927, the delegates, notwithstanding the vigorous promotion in the wake of World War I of a system designed to create interdependence and reciprocal confidence, acknowledged that an award could not even begin to have obligatory force outside its country of origin until that country had positively declared the award to have executory force under its law. Plainly, there was no question what legal order gave controlling effect to the award.

Mid-20 $0^{\text {th }}$ Century, life on this planet changed in three ways of fundamental importance for our story. The first development was a phenomenal expansion of international economic exchanges. Second, the aftermath of World War II was a 
period of imperial dismantlement. With dizzying speed, a world in which a majority of people were not citizens of their own countries, but of colonies, was turned right side up. It is an astonishing fact that a majority of States established by 1970 had not even existed 25 years before. The single year 1960 saw the accession to independence of the greatest number of states ever seen. Each was now in a position to create its own legal order. Each now had borders that defined international trade.

The third change was noticed only by the handful of people concerned with the principles and mechanisms of the arbitral process, which they hoped to adapt to this complex new world. The New York Convention radically reengineered the mechanism of the 1927 Geneva Convention. Henceforth, awards were, and remain, entitled to enforcement in another country under the control of its judges, abandoning the requirement of a prior order of enforcement by the courts of the country of origin. Specialists have ever since referred to this as the abandonment of the need for double exequaturs (a technical term for orders that an award shall have executory force).

The pluralistic thesis is perhaps most precisely described as the perception that a multiplicity of legal orders may ensure the efficacy of arbitration. This insight may not lead to tidiness and predictability. But the vision of an unknown set of potentially relevant legal orders does correspond to the reality of international life. The territorialists may well say that their steady focus on the law of the place of arbitration enhances predictability, but as already observed, that can be so only to the extent that one is concerned with inconsistency between the law of the place of arbitration, on the one hand, and the law of one particular place of execution, on the other. The territorialist doctrine cannot account for the fact that two enforcement fora, each considering whether to recognise an award, may perfectly well come to different conclusions, for example as to the arbitrators' respect for due process as a precondition of enforcement. More generally, Article $\mathrm{V}(2)$ of the New York Convention plainly leaves it to any of a multitude of enforcement fora to evaluate the conformity of an award with their particular conceptions of arbitrability or public policy. It is impossible to deny the plurality of legal orders that may give effect - or not - to arbitration agreements and awards is not a theory. It is simply a fact.

Like so much of life, this pluralism may be chaotic. Depending on the international features of a particular case, the potential plurality is infinitely variable. It is not defined ex ante. True, many cases involve no factors extraneous to the national setting. But in the end, the potential legal orders that may be called upon to make arbitration effective in any given case will not have been finally identified until the arbitrants have finally lain down their arms. The legal order of the place of arbitration may play no role whatsoever in the practical outcome. To the contrary, the legal order of a country not even contemplated at the time of signing the arbitration agreement may be decisive. Above all, in most situations, as in Maitre Dupont's case, even the model of plurality does not, in fact, need to 
operate at all. Arbitration makes its entry and exit without any manifestation of any national legal order other than the diffusely focussed expectations of the parties.

\section{THE THESIS OF AN AUTONOMOUS ARBITRAL LEGAL ORDER}

A vision has been growing for half a century in the minds of a succession of French scholars. Its resonance, in France and elsewhere, has extended to judicial pronouncements, but not to legislation. The latest avatar of this intellectual project is a succinct monograph published by Emmanuel Gaillard in 2008, Aspects philosophiques $d u$ droit de l'arbitrage international, ${ }^{5}$ in which the author answers the 'fundamental preoccupation' with respect to arbitrators' 'power to judge' by reference to something which, he contends with ostensible simplicity, operates outside any national legal order, be it that of the place of arbitration or of the place of execution of an award. This is 'l'ordre juridique arbitral.

It is easy to see why the proponents of this postulate reject the territorialist approach; their perceptions of its deficiencies are the same as those developed above. But why are they not content with the pluralistic thesis?

Gaillard does not challenge its correctness, but rather its consequences - the danger that we may founder on something he refers to as 'the reef of lex executionnisme'. 6 He explains that this shipwreck would be the result of having to consider that the legal foundation of any award is the totality of all legal systems which might be called upon to enforce it. This would, he argues, give primacy to the least favourable norm - 'in defavorem arbitrandum'.; hence, the need for a new conception of an autonomous legal foundation for arbitration.

Gaillard's logic might have found itself on solid ground if our pluralistic world actually worked in this fashion. Fortunately, it does not. Arbitrators do not examine the validity of the arbitration clause, or of their appointment, under the laws of every country that might conceivably be approached as an enforcement forum. Nor do they have a duty to do so. Indeed, that task would be impossible, unless they could read the parties' minds, predict future tracing of assets, and find a crystal ball to reveal where the res judicata embodied in an award might variously be brought to bear by any number of affected parties. Moreover, if Gaillard's vision were correct, any tribunal including a woman, or an atheist, should declare itself lacking authority because somewhere a possible execution forum might require that arbitrators be male, or that they profess a certain faith.

Gaillard's references to the rules of the Internatinal Chamber of Commerce (ICC) and the London Court of International Arbitration (LCIA), to the effect respectively that arbitrators shall make every effort 'to make sure that the Award is

${ }^{5}$ E. Gaillard. Aspects Philosophiques du Droit de l'Arbitrage International (Leiden: Martinus Nijhoff Publishers, 2008).

6 Gaillard, n 4 above, 58-60. 
enforceable at law' and 'to ensure that an award is legally enforceable', is misplaced. It seems odd indeed to think that their duty to strive for the highest degree of enforceability of awards means that arbitrators must reject claims because somewhere, in a place where enforcement may conceivably be sought, there is a possibly applicable rule which might be interpreted to the effect that the award would not be recognised.

It is hard to resist the impression that the filaments of this proposed order float in the ether like gossamer:

- the putative fundaments of this legal order 'correspond' to a 'strong perception' on the part of arbitrators that they do not render justice in the name of any state, yet have a jurisdictional role in the service of the international community';

- they are distilled by arbitrators 'penetrated' by the idea of applying substantive 'transnational' rules rather than fixing on a single national law determined by rules of conflict of laws;

- they reflect a 'vast movement acknowledging the merits of recourse to arbitration' in international trade;

- the order is reflected in a 'current' of 'transnational' law, yielding a 'positivist perspective' due to the 'broad agreement' of states with respect to the criteria by which arbitration is recognised as valid and worthy of their sanction;

- a 'bonus' is given to laws which are part of the 'dynamic' of the 'general evolution' as opposed to those which remain 'outside this movement';

- we thus move from the 'monolocalisation' of arbitration to its 'multilocalisation' and finally reach a triumphant 'transnational representation' of arbitration derived from 'tendencies susceptible to flow from the normative activity of the community of States'.7

In verity, most of Gaillard's demonstration falls ironically into the same trap as that of Mann's 1967 article - albeit with the objective of promoting a contrary thesis - namely looking at substantive rules for deciding a dispute as though they were reflections of a legal order giving effect to the process itself, ie the focus of Dupuy's essential question. When Gaillard focuses on the 'more delicate' matter of the recognition of the 'ordre juridique arbitral,, 8 he says that it 'flows from the will of States, which does not prevent it from being seen as an autonomous legal order' and thus puts his entire construct fatally in harm's way. For the international legal order of states has been painstakingly (if incompletely) constructed on the basis of unanimity. States have never accepted that the norms of the international

\footnotetext{
7 ibid, 60 et seq

8 ibid, 84.

9 ibid, 91.
} 
community are derived from 'progressive tendencies' embraced by other states; they insist on their own individual adhesion. They are even less likely to embrace such amorphous norms as limitations on their laws, in their national space, when dealing with a private-law feature like arbitration.

Gaillard contends that this order is not, as he puts it, 'opposed to national law, but on the contrary is founded on the normative activity of States'.10 The 'objective of the exercise' is to distinguish the rules that have been 'widely acknowledged' from those which proceed from 'un particularisme exacerbé ou désuet. This naturally puts a premium on the discernment of authoritative jurists, who might inspect an array of laws assembled before them like so many cadets, giving a thumbs-up when they somehow perceive that one of them is 'widely acknowledged', or a thumbs-down when they somehow determine that another is just a bit too jejune or retrograde. Yet it must be said that such pronouncements are unlikely to go down well with judges who would be violating their oath of office if they showed fealty to a 'transnational' order rather than to the order of the State that appointed them.

Above all, even if this French thesis were correct, it is difficult to see how it achieves anything not already available under the pluralistic thesis. If national judicial authorities embrace awards that apply transnational norms or trade practices, there is no warrant for concluding that they thereby acknowledge another 'legal order' any more than their acceptance of 'customs of the diamond trade' means that they recognise a legal order established in Antwerp. What courts say is quite simply an expression of the legal order of which they are a part; it can be nothing else.

Perhaps one day national judges will embark on learned assessments of whether certain phenomena are to be given legal effect, irrespective of what their own positive law would say, because such is the consensus of the "normative activity' of progressive states - perhaps vanguard states which are (still?) in the minority, but should be given greater weight than the retrograde majority. But that will, it seems, have to await a new race of judges with a radically new perception of their duties.

Gaillard seeks support in various French judicial pronouncements to the effect that arbitrators are not integral parts of the judicial organisation of the State' of the legal seat of arbitration. Such comments, however, prove only that the French legal order is willing to give effect to arbitral awards when enforcement is sought in France without concerning itself with the views of the courts of the seat. It does not demonstrate the existence of an autonomous 'arbitral legal order'. It is but the reaction of a single national legal order of the multiplicity of orders which may have the occasion to play a role in the life of an arbitration. Nor does the author's emphasis, when citing the reference of the Cour de cassation in the Putrabali case to the foreign award's status as 'une decision de justice

10 ibid, 77. 
internationale, ${ }^{11}$ add anything to the balance; those words are immediately followed by these: 'the validity of which is examined by reference to the rules applicable in the country where its recognition and enforcement are sought.' In other words, it is another acknowledgement of the variety of potential orders. It is hard to see why anything more is necessary - unless it is somehow suggested that the liberal rule of recognition developed in France must be followed by other legal orders as well because it is commanded by an autonomous legal order. But that would be a vast and radical leap and does not appear to be even implicitly demonstrated by Gaillard - nor indeed the many eminent authors he cites, from René David to the present day.

The English Court of Appeal, it seems, was too quick to attribute exotic characteristics to French law when it examined the case of Dallah v Pakistan.12 Dallah is a Saudi trading group. It had won an ICC arbitration in Paris against the Government of Pakistan. The relevant contract had been entered into between Dallah and a Pakistani trust created by Presidential Ordinance, but dissolved a few months after signature. Dallah considered that the contract was attributable to the Government of Pakistan. This gave rise to a debate which the Government argued should be decided under its law, while Dallah urged the application of Saudi law. The arbitral tribunal rejected both arguments. One might have expected the arbitrators to apply French law, faute de mieux, in consequence of the parties' agreement to arbitrate in France. Instead, they held that the issue of the Government's status in the arbitration should be decided by 'those transnational general principles and usages which reflect the fundamental requirements of justice in international trade, and the concept of good faith in business. ${ }^{13}$

The English Court of Appeal, unsurprisingly, found that it had plenary authority to examine whether the award was susceptible to enforcement in England. The judges noted that the words of the Arbitration Act, echoing those of Article V(1)(a) of the New York Convention, required that the validity of arbitration agreements be tested against 'the law of the country where the law was made'. Accordingly, the English courts conducted an in-depth investigation into French law to determine Pakistan's status under the arbitration agreement, although paradoxically the tribunal seated in France had done no such thing. All of this is generally interesting, but the judgment of Lord Justice Rix is of particular moment here. In dictum, Rix considered whether Dallah's case might be assisted by reflecting on the discretion that exists under the New York Convention to enforce awards notwithstanding their annulment in the country of origin, but noted that this possibility appeared to depend on a French 'theory of arbitration',

11 PT Putrabali Adyamulia v Rema Holding et al. [29 June 2007] Cass. civ. Ire, (2007) Rev. Arb. 507.

12 [2009] EWCA Cir 755; [2009] 30 EG 67 (CS).

13 ibid at para [24]. This rather un-English formulation was produced by a tribunal presided over by Lord Mustill. 
not recognised in England, to the effect that arbitrators derive their authority from a transnational legal order. ${ }^{14}$

Well, there may be such a theory circulating in France, but it simply cannot be French law. The French courts may say they have adopted, let us say, the doctrine of the duty to mitigate damages because it is necessary for everybody to obey the Man in the Moon, but that does not make the Man in the Moon a universal lawgiver. It means only that the French courts recognise a duty to mitigate damages. That is all an organ of the French legal order can do, ie to establish a rule for itself. A proclamation to the effect that this is done to give effect to a supranational order would simply be ultra vires. French law cannot will into existence something which is larger than itself. Courts in other countries may well follow the same rule, be it the duty to mitigate or a particularly favourable way of treating arbitration. That does not prove the authority of the Man in the Moon, no matter how adamantly commentators insist that he deserves the credit. It means only that each of a number of legal orders has, for whatever reasons similar, different, or contradictory - adopted the rule in question. The text books of comparative law have for generations been filled with examples. There is nothing new here at all.

The development of international arbitration surely owes a disproportionately large debt to French law and to the conceptual advances of French judges and scholars. Nowhere else have the twin lodestars of freedom and internationalisation, combined in the conception of a voluntary process that accommodates the reality of a transnational society, shone so bright. ${ }^{15}$ Yet, the zeal of those who make extravagant claims may do more harm than the resistance of non-believers and scoffers. The proposition that an effective legal order may be built upon diaphanous abstractions like positive perspective or transnational dynamics is more likely to impede than to facilitate respect for the arbitral process.

\section{THE FLUID REALITY}

Reality does not so much contradict the three theses we have now examined as it ignores them. It notionally collides with the territorial postulate, but this hardly matters since that thesis is outdated. Reality is more consistent with the pluralistic concept, but, as we shall see, tends to transcend it without hesitation. Finally, reality can safely disregard the third model because, as seen, it is no more than pluralism, masquerading as something more grand. Even the pluralistic model, however accurate as far as it goes, is too restrictive and therefore unsatisfactory. It

\footnotetext{
14 ibid at para [75]. However, in the following paragraph, Rix went on to suggest that the true basis for this outcome might be not a 'free-standing discretion', but rather - simply - a rule of French law.

${ }^{15}$ For a recapitulation in English of France's unique contribution as it could be assessed already two decades ago, see A. von Mehren, 'International Commercial Arbitration: the Contribution of French Jurisprudence' (1986) 46 Louisiana Law Review, 1045.
} 
leaves out too much of the picture. We must revise it if we are to perceive the effective role of arbitration accurately.

As the foundation of arbitration, or more precisely a sufficient foundation for some arbitrations, this revised conception does not depend directly either on law or judges. It therefore does not seek to attach itself, in the manner of the Parisian thesis, to the somewhat dreamy and self-contradictory premise of an 'autonomous' order recognised by the very state orders from which is purports to be free.

Some would object that if it does not secure a place in the ordering of a state, this fourth conception cannot refer to a legal order at all. Even if that objection were accepted (although the discussion below does not), this fourth perspective must be considered seriously because it corresponds undeniably to a social institution which is often highly effective in practice. It is obviously the most autonomous of all ways of perceiving arbitration. When this revised model of pluralism operates, arbitrants would no doubt on occasion be pleased to qualify for assistance from the machinery of the state. On occasion, that same machinery may intervene to exclude the possibility of arbitration. But the point is that this is a vision of arbitration which functions routinely without judicial assistance. At the greatest level of generality, this notion of private social systems, which secure the enforcement of rights and obligations defined by its constituting group, is not unique to arbitration. Such systems may be admirable or not, from the extremes of criminal syndicates and oppressive religious sects to trade associations and sports federations. Some such arrangements may operate, to a greater or lesser extent, against the background of expectations of what would happen if disputants went to law. In other contexts, there simply is no relevant or realistically available public jurisdiction.

A seminal exposition of this vision of legal orders was published in 1918 by Santi Romano under the title L'ordinamento giurdico - 'The Legal Order'. ${ }^{16}$ It remained an Italian secret for half a century, until Spanish, French, and German translations appeared. A worthy adversary of Kelsen, who ended up at Berkeley, publishing lengthy works for many years in English, Romano never left Italy and wrote in his native language. It is a considerable loss for the Anglophone world.

Law must ultimately be founded in social reality, Santi Romano reasoned. Social reality may create a legal order that ignores the formalistic insistence on an elusive ultimate norm, be it Kelsen's Grundnorm or - to anticipate - Hart's (secondary) rules of recognition. To posit that a legal order cannot exist without a moral foundation struck Romano as naïve and analytically unhelpful. But of course, he could have conceded the point without altering his overarching insight; many social groups proceed from moral precepts. For Romano, every organised social group is a kind of legal order. It may be superior or inferior to a nation-

16 The book was updated in 1945 to respond to critiques. The references here are, owing to my linguistic limitations, to the second edition of the French translation by Professors L. Francois and P. Gothot: L'Ordre Juridique. (Paris: Dalloz, 2002). 
state, or even parallel: the international community, an institutionalised church, subnational collectivities, professional and trade organisations, associations of myriad types - even families, including criminal 'families'. ${ }^{17}$

Social groups capable of generating a legal order, in Romano's view, are not limited to those without which the individual cannot survive; they include voluntary communities (or interest groups) from which the individual may exit. It follows that legal orders may survive within a greater legal order which tolerates and indeed nourishes them, but does not care to impose itself in the domain for which the subgroup in question prescribes its rules. It is a commonplace observation that empires at their apogee, confident in their power and immortality, from Rome to Britain, have tended to permit a profusion of local legal arrangements.

Santi Romano was obviously a pluralist. A foreign judgment enforced by a state has not been 'naturalised', he reasoned; the effect of enforcement is given to the judgment by virtue of a 'national' norm; no foreign legal order could so ordain. ${ }^{18}$ This deftly disposes of Francis Mann's territorialist simplicities, and seems wholly consistent with pluralistic thesis as described above.

But we did not need Santi Romano to leave the territorialist thesis behind us. His remarkable contribution is rather a vision of pluralism which goes further than to consider the relationship between national legal orders among themselves, and allows us to see the success of arbitration through the prism of legal orders different from that of the nation state, and, in some contexts, more efficient than the latter. In this fundamental respect, a close reading of Herbert Hart shows that he moved some distance away from Kelsen and toward Romano. With respect to the ultimate questions of parliamentary omnipotence, for example, Hart conceded in The Concept of Law that ultimately the determination of what is 'accepted' is an 'empirical' matter; that the authority of courts to decide what is constitutional depends on the circumstance that 'a vast area of law ... raises no doubt'; that in the end 'all that succeeds is success'. ${ }^{19}$ Yet again:

\footnotetext{
17 There is a vital difference between enforcing a leader's command 'because he wants your coat' and 'because we depend on discipline'. The former is an arbitrary and personal exercise of power; the latter has to do with the group's self-regard as an enduring normative ordering, however primitive (in this case little more than a rule of recognition of authority). Max Weber was saying as much when he distinguished between enforcement of 'conformity to a norm as such, i.e. because of its being formally accepted as binding' and enforcement of conduct 'because of considerations of expediency or the other material circumstances' (M. Weber, Law in Economy and Society, M. Rheinstein (ed) (Cambridge, Mass.: Harvard University Press, 1954), 12-13.

18 Romano, n 16 above, 138.

${ }^{19}$ H.L.A. Hart, The Concept of Law (Oxford: Clarendon Press, 2nd ed, 1994), 150, 152, 153. Hilary Mantel imagines that Thomas Cromwell said it better in an interior monologue, as chief minister of Henry VIII drafting the Act of Restraint of Appeals in 1533 (by which Rome's legal dominion over England was severed): 'When you are writing laws you are testing words to find their utmost power. Like spells, they have to make things happen in the real world, and like spells, they only work if people believe in them.' Wolf Hall (London: Fourth Estate, 2009), 574.
} 
...the rule of recognition exists only as a complex, but normally concordant, practice of the courts, officials, and private persons in identifying the law by reference to certain criteria. Its existence is a matter of fact. ${ }^{20}$

Where the structures of the state do not 'succeed', we observe as 'a matter of fact' that other arrangements fill the void. Indeed, such non-state mechanisms may surpass or ignore less vital institutions proposed by the state. As Pierre Mayer has observed, once one sees that the ultimate rule depends on the fact of its social acceptance, the vision of a legal order cannot be reduced to an abstract normative system. Pretentions of legitimacy are not the real thing. It is necessary, and sufficient, that the relevant body of norms be acknowledged as a matter of social reality. Dismissing objections to Santi Romano on account of his alleged 'confusion' of social order as opposed to a disembodied complex of norms, Mayer concludes (in his introduction to the most recent French translation of Santi Romano's masterpiece):

In the end, we may well ask whether the true oddity is not this furious insistence on excluding the slightest portion of living reality from the definition of a phenomenon which, after all, characterises man's life in society. 21

Precisely because in so many ways it replicates the judicial forms of an adversarial process, arbitration is an obvious potential vehicle for social arrangements constituting legal orders outside the conventional statist model. This is by no means an acceptance of the notion of an 'arbitral legal order'. Render unto Ceasar the things that are Caesar's; when a state accepts to give effect to such private arrangements, for instance by enforcing arbitral awards, it does so by application of a norm of its own, that is to say the expression of its own legal order. Santi Romano's insight is that other legal orders may function without intersecting with national orders at all. There are signs that Romano's reality is in the ascendancy. It may fill the vacuum when public institutions fail. It may be the hallmark of a fluid legal universe, with significant elements of self-governance, as the arbitrants themselves, replacing the legislative and the executive arms of the state, create norms and ensure their sanctions. This immensely important phenomenon, and its limits, compels us to make important conceptual moves.

${ }^{20}$ Hart, n 19 above, 110 (emphasis added).

21 Preface to the second French translation of L'ordre juridique, n 16 above: 'Le plus étrange n'est-il pas finalement cet acharnement à exclure jusqu'à la moindre parcelle de réalité vivante de la définition d'un phénomène qui caractérise, malgré tout, la vie de l'homme en société?' 


\section{THE NECESSITY OF INVENTION}

Most human beings living on this planet today do not have the remotest chance of obtaining decent justice from their courts. This is a luxury available to more or less important segments of the population in rich countries - and to hardly anyone elsewhere. The have-nots can hardly be told to content themselves with hopes for justice for their descendants. One cannot fail to reflect that the thirst for decent methods for solving disputes will in these circumstances generate alternatives ranging from informal pronouncements by trusted elders in poor Anatolian villages to elaborate arbitral awards rendered in the context of vast business dealings. Those who would seek to prohibit such alternatives in order to preserve the primacy of public courts should first consider whether the public systems to which they command their fellows to cast their fate are dysfunctional.

These observations about the state of public justice are neither gratuitous nor anecdotal. Vast resources have been expended studying matters of governance throughout the world, first and foremost legal systems. Whether governance has improved as a result is debatable. But it is a fact that these well-intentioned programs have given rise to a vast body of detailed reports on the state of judiciaries around the world. These reports are readily available from international organisations, national development organisations, or private foundations. Anyone with access to a computer can quickly access thousands of pages written by highly qualified development specialists. They are generally disheartening.

The conclusions of typical general studies were illustrated by the very titles of two World Bank reports of investigations conducted in the early years of the new Century. One was called 'The Inequality of Influence' (2003), ${ }^{22}$ and introduced the concept of crony bias, associated with the subversion of institutions, tax avoidance, corruption and - for those who are not in on the game - the inclination at all cost to stay away from courts. The other bore the blunt title 'Misrule of Law' (2001).23

Around the world, such studies conclude that ordinary citizens expect little from the courts, and that indeed they are right, as a consequence of long delays, political influence in the courts, ignorant judges, corruption, hostility toward women and the poor, prohibitive costs, and lack of transparency. Perhaps the bleakest outlook is that of countries characterised by fragile or paralysed institutions, where whether disputes are resolved, or not, is a function of personal influence.

Judicial dysfunctionality constitutes an enormous handicap to social and economic development and disproportionately harms the poor. This is why international institutions interested in development expend so much effort on matters of governance. The return-on-effort is modest at best. As the chief

22 J. S. Hellman and D. Kaufmann, 'The Inequality of Influence' (Stanford Corruption Workshop, 30-31 January, 2003).

${ }^{23}$ D. Kaufmann, D. 'Misrule of Law' (World Bank, 2001) at

http://www.worldbank.org/wbi/governance. 
economist of the International Monetary Fund wrote in 2004, 'institution building' has not benefitted from 'much guidance from academia'. He continued, starkly:

'... a better starting point for analysis than a world with only minor blemishes may be a world where nothing is enforceable, property and individual rights are totally insecure, and the enforcement apparatus for every contact must be derived from first principles...'24

When the legal order provided by a state proves unsatisfactory to particular segments of society, alternative methods are devised. These methods may seem more or less legitimate. At one extreme, the relevant state may have become a sorry fiction, unable to provide either security or justice. Such circumstances are likely to engender sympathetic understanding for the emergence of alternative arrangements by which citizens strive to attain a measure of predictability in their lives. At the other extreme, the relevant state may be an example of acceptable efficiency and democratic refinement, and the creators of the alternative arrangement a band of rascals who wish to enrich or empower themselves by means of ruse or violence. Their 'codes' of discipline and retribution are repulsive. In between, there are groups who simply want a more efficient system for the enforcement of rights and obligations, with respect to which our sympathy is likely to depend on the degree to which we find that their arrangements are compatible with the values and objectives of society at large: public policy.

Yet, all social groups, as Santi Romano saw it, produce legal orders. Since law is the reflection of a social ordering, it excludes any feature which at its heart is the product of arbitrariness or opportunistic force. The legal order emerges from a necessity of coexistence: overcoming the weakness of individuals by providing a lasting basis for life in society 'through the creation of social entities more enduring and stronger than individuals'. And so a system emerges from the accretion of a multitude of arrangements. A legal order is therefore not the product of a set of positive laws, but rather the inevitable result of the formation of a social group. As Romano put it in a central passage, the legal order 'is an entity which partly moves itself according to norms, but mostly moves the norms as pieces, so that norms constitute rather the object and the means of its activity rather than an element of its structure'.25

This vision of the environment in which arbitration operates has the considerable advantage of realism. It is all-embracing and therefore untidy. All processes qualify, from the lofty formalism of grand tribunals established with pomp and circumstance to the most casual hint from a personage whose lifted eyebrow is all that is required in a particular milieu. The norm is secondary. What

24 R. Rajan, 'How Useful are Clever Solutions?' (2004) 41 Finance and Development, 57.

25 Romano, n 16 above, 15-16. 
counts is the acknowledged authority, moving the norms like the pieces of Santi Romano's metaphor.

In this vision, crime families or religious groups are to be considered legal orders as long as they provide a modus vivendi 'more enduring and stronger than individuals' and preclude 'arbitrariness or opportunistic force'. The norms are not what make the system; it is the system which uses them to its ends. The rules of a particular group, to outsiders, may seem odious or irrational, but they are effective for that group and therefore constitute a legal ordering. True enough, the code of a criminal gang or that of a cult (apart from their distastefulness to citizens of the wider society) may be vastly less complete than the collected laws of a state, but that is not a significant criterion in comparison to the test of truly regulating social life. Some national legal orders, irrespective of the voluminous tomes of laws ostensibly in force, represent virtually nothing in terms of regulating life in society, whereas a perfectly effective legal order may be achieved by a single rule if it is sufficiently anchored in the community: 'the Chief Druid shall be elected on the $1^{\text {st }}$ of May each year, and everyone shall do as he or she says until the next election.'

Real-life examples of legal orderings involving arbitration are seldom primitive. To the contrary, their textual underpinnings - their constitutions - are frequently elaborate. To a significant degree, this is so precisely because they were conceived to avoid the need for controversial interpretation by state organs indeed to function without any intervention by state authorities.

To examine the interpenetration of state and non-state legal orderings, one naturally turns to the examples of well-established private arbitral institutions operating across borders. They have flourished for many decades and have done so by evolving quickly in response to the dynamics of their transnational environment. As a result, they have transformed both their nature and their operations. This is specifically so with respect to their relative position as compared to national orders. As late as the 1950s, the International Chamber of Commerce's arbitration system was a diffident, puny institution in comparison to the potent state orders then holding sway. Today, ICC arbitrations - and other similar types of arbitration - provide the normal method by which international commercial disputes are resolved, and an overwhelming proportion of such disputes are so resolved without any need to refer to state authorities of any kind. For their part, the states extant today are a motley crew. Anyone who wishes to insist that various failed states, simply because their flags fly at the UN, are more entitled to be considered 'legal orders' than, say, the institution of arbitral proceedings conducted under the rules of the United Nations Commission on International Trade Law (UNCITRAL) as supported by the New York Convention, is perhaps a prisoner of hollow definitions.

The mechanism of arbitration under rules developed by the ICC was launched at a congress held in London in 1921, shortly after the founding of the ICC itself. Owen Young, Chairman of the Commercial Arbitration Committee of the US Chamber of Commerce and a well-known businessman, urged that it was important to create effective solutions 'outside the law'. He introduced this 
striking notion by saying that the ICC's success in the field of international commercial arbitration

...will depend on the recognition by the Chamber and by its individual members of the inherent difficulties and complexities of the situation. The most important of these difficulties lies in the fact that, generally speaking, the business men of continental Europe rely upon a legal sanction for the carrying out of arbitral decisions, whereas in the United States, as well as in England and the South American countries, a moral sanction has been shown to be, certainly for the present, more effective than a legal sanction. To ensure the cooperation of these countries, therefore, some system of arbitration outside the law must be provided.

Young went on to imagine that some arbitral awards would not be enforced by legal processes,

...but upon a moral sanction, such as can be exercised by the International Chamber of Commerce itself, and by member National Committees, with all the force that business men of a country can bring to bear upon a recalcitrant neighbour...Before agreeing to conduct an arbitration outside the law, even when both parties should join in a request, the International Chamber should be convinced that the business men of both countries concerned are sufficiently well organized and that the business organizations are willing to exert moral pressure, if need be, in favor of carrying out the arbitration decision outside the law, and are sufficiently influential to make such pressure effective. ${ }^{26}$

The expression 'outside the law' was perhaps not well chosen, since it is so readily converted to 'out-law'. That is certainly how it is perceived, time and again, by critics who detect, in all initiatives to avoid the ordinary public courts, an intent to undermine the implementation of public policy. ${ }^{27}$

Of course one way to control arbitration would be to destroy it. If that were possible, however, one would have to disregard an apparent worldwide consensus that arbitration has made positive contributions to the rule of law in ways indispensable to exchanges that benefit the international community. The freedom to arbitrate seems to be broadly acknowledged as a universal value, reflected today in the success of the UNCITRAL Model Law on International Commercial Arbitration. To dismantle arbitration would also imply refusal to accept the use of such tools in environments of institutional disarray, where

${ }^{26}$ ICC Rules of Conciliation and Arbitration (Brochure No 2, 1923), 2, quoted in G.L. Ridgeway, Merchants of Peace (New York: Columbia University Press, 1938), 322.

${ }^{27}$ See, eg, H. Kronstein, 'Business Arbitration - Instrument of Private Government' (1944) 54 Yale Law Journal, 36 . 
transnational exchanges would otherwise comport unacceptable risks. It would mean the rejection of all attempts to secure justice in contexts where there is no functioning public judiciary. History suggests that this objective (independently of its doubtful merits) would be unrealistic.

The example of commercial arbitration has been studied extensively in terms of its interface with national courts (viewed both as facilitators or supervisors). It is the principal focus of most textbooks on arbitration. It may be instructive to consider two newer entrants.

There is a single global Internet, of which the essential core element is the socalled root zone of the Domain Name System (DNS). As a purely operational matter, this root is controlled by the Commerce Department of the US Government. For the government of a single state to regulate such an important global resource would be highly controversial, likely to generate political pressure to create competing systems. This would be a retrograde development, a Tower of Babel in cyberspace. The US Government has entered into contracts with a not-for-profit corporation, Internet Corporation for Assigned Names and Numbers (ICANN), to provide singularly important regulatory services: allocating and assigning domain names and IP ('Internet protocol') addresses, coordinating the DNS root name server system, and organising the process of 'policy development... related to these technical functions'.

Controversies have arisen with respect to numerous policy issues. Against the background of the possibility that the US Government could reclaim the power and functions it contracted to ICANN, the latter operates under Articles of Incorporation and Bylaws in conformity with its state of incorporation (California). Critics of ICANN's governance have complained that this outsourcing of regulation impairs accountability, in that ICANN's decisions escape the ordinary requirements of administrative law, such as transparency, due process, and judicial review. As one persistent critic has put it, the DNS should not be regulated 'through contracts and winks'. ${ }^{28}$ On the other hand, that these functions should be subject to US administrative law would most certainly be perceived as national assertion of dominance over an international resource, and so ICANN continues, as a work in progress, to seek to satisfy its global constituencies through refinements of three principal features: First, its work is done in conditions of transparency, with meetings, contracts, and protocols routinely made accessible to the public for timely comment. Second, its Bylaws require a cosmopolitan Board, including members from all continents, as well as a Governmental Advisory Committee 'open to all national governments' - which holds frequent meetings around the world that resemble nothing so much as typical conclaves of international organisations. Third, the Bylaws also provide that an independent review board...operated by an international arbitration provider' may be asked by a complainant to declare whether actions of ICANN's

28 A.M. Froomkin, 'Form and Substance in Cyberspace' (2002) 6 Small \& Emerging Business Law, 93. 
Board are consistent with its Articles and Bylaws, which themselves require that ICANN act 'in conformity with international law.'

This is doubtless a peculiar legal construct. It defies categorisation; it cannot accurately be described as the manifestation of the legal order of a state, and yet it constitutes the ordering of an important and remarkably cosmopolitan community, made up of delicate compromises and intense controversies, adjusting over time as its members appraise events, processes, and decisions. If this is not law in action, in the full glory of conceptual ferment, what is?

Another illustration of the remarkable effect of non-state orderings comes from the world of sports, which in modern time has become a vast international industry. It has generated an arbitral mechanism which operates in a context which gives it great efficacy. Although it has been in existence for little more than two decades, the Court of Arbitration for Sport (CAS), located in Lausanne, is extremely active and the awards of arbitrators operating under its rules are given full and immediate effect. It is easy to see why this is so in disciplinary cases; an athlete who is suspended for a doping offence simply will not be given the credentials to compete because the federations who organise competitions adhere to regulations which accept CAS awards as ultimate appellate decisions. But CAS also achieves finality and efficacy with respect to contractual disputes, in unique and instructive ways, as the following example will show.

In early 2002, a Brazilian football player signed a four-year contract to play for a Mexican club called 'Sinengía Deportiva', or more commonly 'Tigres'. He was first paid a transfer fee of US $\$ 1$ million and was thereafter entitled to receive a monthly salary until the end of the fourth season.

The player stayed with the team for one year only and then returned to Brazil for good. The international football federation, FIFA, promptly suspended him from playing worldwide. Within a few months, a Brazilian labour court ruled that he was entitled to pursue his career. That judgment freed him to take employment with a Brazilian team known as 'Atlético Mineiro'.

Tigres felt hard done by. They had paid one million dollars in order to procure the services of the player for four seasons, not just one. But how were they to be made whole? True, the club had an employment contract with the player. True, they might get a judgment in their favour from a Mexican court. But then what? Even without any complicating factor, one cannot expect that a Mexican judgment would readily be declared enforceable in Brazil. Even if by unexpected good fortune, it were homologated - to use the term favoured in Brazil - how could it be enforced against the player? What reason would there be to suppose he had saved his money in a single, convenient, transparent account to accommodate the Mexican judgment creditor? And of course there is that complicating factor: a Brazilian court had declared that the player was entitled to pursue his career with a local team. This entitlement, as one would expect, was proclaimed in stirring language about every individual's right to work. If Tigres 
operated in the familiar environment of imperfect coordination among state legal orders, its prospects were grim.

Not so in the modern context of the globalised football industry and CAS. Tigres had no difficulty in enforcing their claim. They first complained to the FIFA Players' Committee, which found the player to have breached his contract and ordered him to restitute the US $\$ 1$ million transfer fee. If he failed to pay, Atlético Mineiro would be jointly liable. This decision was challenged by the player and by Atlético Mineiro before CAS, and three arbitrators were duly appointed.

Full arguments were heard before the arbitral tribunal - notably as to the interpretation of the employment contract and as to the principle of joint liability. As to the former, applying Swiss law and the FIFA Regulations, the arbitrators concluded that the damages should be reduced to US\$750,000 on account of the one year the player did perform. As to the latter, the position was clear: the FIFA Rules explicitly hold teams jointly liable for the breach of a prior contract committed by any player they chose to employ. Accordingly, if the player were to fail to pay the US $\$ 750,000$ within 30 days of the award, Atlético Mineiro would be required to make the payment.

Atlético Mineiro could be counted upon to make the payment, because otherwise it would face a disciplinary action by the Brazilian federation in the form of a relegation from the premier division. For the club not to do what was necessary to avoid that sanction - ie to pay Tigres - was really quite inconceivable. The Brazilian federation, in turn, could be counted on to ensure compliance by its member, Atlético Mineiro, because otherwise the federation would face disciplinary action by FIFA in the form of exclusion from international competition. Brazil out of the World Cup? 'Inconceivable' is not an adequate word! 29

What about the Brazilian judgment which declared the player free to pursue his career with Atlético Mineiro? To the extent that it is in contradiction with the CAS award (or more likely, vice versa: a Brazilian judge declaring that the CAS award infringed on the players' rights as perceived in Brazil), there is undoubtedly a possible tension between international federations and national authorities. This possible conflict has materialised in many sports, for example in cycling, where Spanish competitors in an international championship event in Spain are subjected to the rules of the Union Cycliste Internationale, with reference to CAS as the ultimate authority, but there is also a Spanish Royal Decree on Sports which gives exclusive final jurisdiction to the courts in matters of doping (apparently due to a fear that local sports bodies may be too tolerant of their star performers). The award in

\footnotetext{
29 On more than one occasion, Brazilian athletes and teams have benefited from the international regime in circumstances where it is doubtful that national proceedings could have been effective, for example the award by which the Ittihad Club of Saudi Arabia was ordered to pay nearly US $\$ 2.8$ million to the Brazilian club Vitória de Bahia (Vitória S/A v Ittihad Club of Saudi Arabia, CAS 2006/A/1195 [award of 7 August 2007]; appeal rejected, with costs, by the Swiss Federal Tribunal [13 May 2008]. The international system would doubtless break down if it were not supported by a strong structure of reciprocal benefits.
} 
UCI v Aitor Gonzalez \& Real Federación Española de Ciclismo (19 December 2006) reasoned that Spain can certainly regulate whatever happens on Spanish territory, but if no accommodation is made for the primacy of international regulations, the consequence would inevitably be that international competitions (which by necessity must be ruled by perfectly uniform rules) would simply be organised elsewhere. ${ }^{30}$ There have been some tense momentary standoffs (not, as it happens, involving Spain), but so far, national and international regulators have respected an intelligent division of domains.

These examples show that the promises and dangers of a great variety of selfcontained systems of decision-making and compliance must be understood. They are real. The facts on the ground are ahead of the theory: experience is not reflected in law courses. But these arrangements uniformly involve lawyerly presentations, insistence on fundamental principles of the adversarial system, and decision-making which is conscious of institution-building objectives. If this is not called law, we need new definitions.

\section{ABANDONING AN OUTDATED MODEL}

The fluid legal order in which arbitration operates undoubtedly works in practice, but, as the old joke asks: will it work in theory? The sting in this witticism is not that theory is inevitably useless, but that when a phenomenon may be observed in practice, it is useless to propose a theory that cannot accommodate reality. Looking at the world today, we must abandon the formalistic dead end of the exclusively statist model.

Little is gained in devising abstract and infinitely debatable definitions and then disqualifying all social arrangements which do not fit. Looking backward and sideways at other human civilisations, we need to explore how societies have sought to achieve social order, and to test models by reference to reality, rather than to reject reality because it does not correspond to our idées fixes. And looking forward - since 'social order' alone is unlikely to satisfy our ambitions, is not the great prize to understand how societies may reconcile social order and policy, on the one hand, with the imperatives of individual human rights? Arbitration, national and international, will be an important part of the world we are building, and many ideas once thought fundamental must be jettisoned.

The irrelevance of courts is already apparent in some environments, even with respect to enforcement. The multitude of states now crowding the world atlas is appallingly disparate in terms of institutional capabilities. It would be tragic if we had no choice but to look to them as the sole founts of law and order. Consider the number of paralysed states which nonetheless fulfil the formal

${ }^{30}$ UCI v Aitor Gonzalez \& Real Federación Española de Ciclismo, CAS, 2006/A/1119 [19 December 2006]. 
requisites of statehood. They are members of the United Nations; they enjoy official diplomatic relations; their borders are formally acknowledged. But on the ground, on the national level of these putative entities, there is nothing that could decently be called law, and in some cases, this has been so for generations: no constitutional legislature, no law enforcement, no judiciary - nothing but a bleak mockery of each of these basic institutions of polity.

But of course even in these terrifying places, there are social groups, and where there are social groups, there will be legal orders. Santi Romano was not the first to challenge the putative sovereign exclusivity of states as proprietors of legal orders. For one, Eugen Ehrlich, a pioneer of legal sociology and a doubter of Kelsen's hierarchical vision of the structure of law, 31 wrote in 1913 that: 'It is not an essential element of the concept of law that it be created by the state, nor that it constitute the basis for the decisions of the courts or other tribunals, nor that it be the basis of a legal compulsion consequent upon such a decision'.32 Laying the foundation for much subsequent legal anthropology, Ehrlich thus accepted that societies lacking formal organs for the establishment of laws and for their administration could provide what Ehrlich called 'living law' as distinguished from the law of the state. A decade later, Max Weber declared robustly, in Economy and Society (1922), that the 'assumption' of the state's possession of 'coercive means' superior to all others is 'anti-sociological'.33 So much for Kelsen, if one understands 'assumption' to cover his premise of the Grundnorm and 'antisociological' to indicate the invalidity of that premise. Weber cited ecclesiastical law as well as communal orderings within imperial Austria, saying that they retained their nature as law 'even when it comes into conflict with 'state' law, as it has happened many times and as it is bound to happen again...' He went on to conclude:

...we categorically deny that 'law' exists only where legal coercion is guaranteed by the political authority. There is no practical reason for such a terminology. A 'legal order' shall rather be said to exist wherever coercive means, of a physical or psychological kind, are available; i.e., wherever they are at the disposal of one or more persons who hold themselves ready to use them for this purpose in the case of certain events; in other words, whenever we find a consociation specifically dedicated to the purpose of 'legal coercion' ...It goes without saying that this kind of coercion may be extended to claims

\footnotetext{
${ }^{31}$ Both men taught at the University of Vienna, but Ehrlich's home was in the Austro-Hungarian province of Bukovina, where he was struck by the co-existence of Austrian law and resistant local normative traditions.

32 Ehrlich's rationale is reflected in the following passage, which is resonant of Romano's thinking: 'The law does not consist of legal propositions, but of legal institutions. In order to be able to state the sources of the law one must be able to tell how the state, the Church, the commune, the family, the contract, the inheritance, came into being, how they change and develop.' (Fundamental Principles of the Sociology of Law (W. L. Moll, trans) (Cambridge, Mass.: Harvard University Press, 1936), 84.

${ }^{33}$ Weber, n 17 above, 16-17.
} 
which the state does not guarantee at all; such claims are nevertheless based on rights even though they are guaranteed by authorities other than the state. ${ }^{34}$

Opponents of this vision insist that it may be of interest as a matter of sociology, but is deficient as a matter of legal analysis. Enter Romano. His was not the perspective of a sociologist; he was a lawyer through and through. $35 \mathrm{He}$ might have entitled his book Legal Institutions because for him the expressions are synonymous, but preferred 'legal order' precisely because he did not want his analysis to be equated with sociological inquiry.

There are political groups with semblances of the medieval mini-states; the modern equivalents of baronies and principalities held together by the raw power to impose and to protect. Kelsen would be useless there, since his fundamental norm is a starting point. Kelsen, one supposes, would just have to wait patiently for how many generations? - until some force emerges to create the order, as he saw it, with a proper Grundnorm and with proper sanctions, thus raising itself to the pedestal where a legal scholar would deign to consider it. ${ }^{36}$

The very concept of a legal order is not particularly ancient; our ancestors did not, it seems, begin to develop it until well into the 19th Century. We could undoubtedly survive without it. Some theorists may well unintentionally have put us in the frame of mind of longing to ignore it. Yet the concept has a number of advantages that facilitate communications about laws, notably their applicability, their internal hierarchy, and their relationship with the law of another order. For our purposes, we need only to consider that a legal order is a set of norms acknowledged by a social group as authoritative, and leave the qualifications that may be claimed with respect to each element of that phrase to a more rarefied debate.

That being said, it seems that progress can be made with respect to some basic propositions. To begin with, we are in a position to determine the validity of the claim that this schematic representation defines the only conceivable types of legal order:

\footnotetext{
34 ibid, 16-17.

35 Apart from L'Ordinamento Giuridico, his two main works concerned administrative and constitutional law. His career was essentially that of a law professor, but one of sufficient eminence to have led to a Senate seat and the presidency of the Council of State.

36 A basic problem with Kelsen was put this way by Julius Stone, in The Province and Function of Law (Cambridge, Mass.: Harvard University Press, 1947), 108: 'It is difficult to see what the pure theory of law can contribute to a system which it assumes to be law, but which it derives from a basic law which it cannot find.' Harold Laski was blunter when he observed that Kelsen's 'pure science of law' is 'an exercise in logic and not in life', A Grammar of Politics (London: Allen \& Unwin, 3rd ed, 1958), vi.
} 


\author{
THE INTERNATIONAL \\ LEGAL ORDER: \\ - universal ambit \\ - multilateral institutions
}

\section{THE LEGAL ORDERS OF STATES:}

- territorial ambit

- unitary institutions

This tidy model is coherent with a number of simple propositions:

(i) The international order covers the planet. It is explicitly consensual; its norms are those accepted by states. (Its institutions are never referred to as 'sovereign'.) These norms are applied by courts of final jurisdiction, be it the International Court of Justice, the International Criminal Court, the WTO Appellate Body, or some other organ specifically so empowered.

(ii) National orders cover the territories claimed by states. Their norms are promulgated in accordance with national constitutional arrangements, typically by legislatures, and are thus imposed on all who fall within their 'sovereign' jurisdictions. These norms are applied by constitutionally designated supreme courts. (These may be more than one, eg to allow a specialised jurisdiction for administrative law.)

(iii) The national legal orders are mature because the members of the international community are by definition sovereign, and the authority of their laws is unquestioned in their territory. International law is designed to deal with relations among these sovereigns. It is a rudimentary order because its authority is limited to what sovereign states are pleased to assign to it.

(iv) The institutions of the two orders are exclusive in the sense that they are not concurrent. The institutions of a state have rules for resolving possible conflicts of jurisdiction, and the same holds true of the institutions established by the international 'community' (ie its constituent states).

There are certainly instances where this model can function. Two states promulgate national laws reflecting conflicting claims over territory between them. They then agree that their border will be determined by the ICJ. The border is duly determined in accordance with international law as the ICJ understands that law under its Statute. That judgment is effective, because each party - even if disappointed with the outcome - finds it in its interest to treat it as such for a variety of conceivable reasons, including that it understands that the UN Security Council may otherwise take action under the UN Charter.

But the modern world simply does not correspond to this neat construct. There are today many international orders, some of them having universal 
aspirations, others not. Those that do not include, for example, the orders created by treaties instituting regional courts of human rights, most remarkably in the case of European states which are simultaneously bound by the treaties of the EU and the European Convention on Human Rights, which extends beyond the frontiers of the EU. Among the international orders aspiring to universality are, eg, the World Trade Organization and the International Criminal Court.

Arrangements arising in the international space may also call upon the application of norms by hybrid organs. Consider the many hundreds of bilateral investment treaties now in force. They are signed by states, and so by definition have a place in the national legal order. Yet they allow for private parties, as beneficiaries of the treaty, to seek international arbitration against one of the signatory states. Such arbitrations may apply national as well as international law. They may give rise to applications to national courts to take a position with respect to the effects of these arbitrations - a matter for the national order in question. They may give rise to disputes between the states signatory by reference to the conduct of one of them as a disputant with a national of the other - a matter for the international order.

National orders may themselves have to give way to the superior normative force of a regional order, to the point that national courts may be required to seek an advisory opinion from the EJC on a point of European law, and must in any case apply European law directly in matters covered by it.

Above all, the simple figure above is defective in terms of what it does not depict, namely the legal orders created by social groups which are neither states nor international organisations of states.

Pluralism in its simplest sense may be called horizontal, in that it envisages the cooperation of a multiplicity of territorially sovereign legal systems. This conception fits rather tidily with traditional conceptions of legal orderings as inherently connected with the territorial domination of states. But the premise of law as within the exclusive dominion of states has for some time been shaken by the observation that legal pluralism is in fact three-dimensional. Its vertical dimension reveals itself when more than one legal order occupies the same space. Like the ICANN and CAS examples described above, many of these non-state systems unmistakably - even assertively - view themselves as legal orderings. They legislate, they establish adjudicatory bodies involving formal adversarial procedures in which professional lawyers participate (and even specialise), and they expect that their array of internal sanctions is such that they need no assistance of state officials to make their outcomes effective.

In the light of such developments, it seems that the proponents of pluralistic, overlapping legal orders create an unnecessary difficulty for themselves if they concede that non-state orders do not view themselves as engaged in governance. To take one prominent example, Boaventura de Sousa Santos, who observes with approval 'the great variety of legal orders circulating in society', seems to be unaware how far things have gone when he quite inaccurately accepts that state 
law is distinctive in being 'the only self-reflexive legal form, that is the only legal form that thinks of itself as law'. ${ }^{37}$

Conversely, sceptics make their case easier by asserting, without any basis for doing so, that non-state arrangements cannot qualify as legal orders because they do not have the ambition of governing; they are not, in Simon Roberts' phrase, 'projects of government'. ${ }^{38}$ True enough, one must share the unease felt by those who fear that an exuberant rush to see legal orders everywhere, even in the most ephemeral arrangements covering only the tiniest slices of life in society, will expand the concept into meaninglessness. There is force in Roberts' argument, as encapsulated in the final sentence of his 2004 Chorley Lecture: 'Uncoupled from governing, de-centred law - like decentred regulation - may well be found everywhere; but in representing it like that, we risk losing all sense of what it is. ${ }^{39}$

This notion of law 'uncoupled from governing' merits greater scrutiny. The truth is that the formal apparatus of positive law proclaimed by a great number of institutionally defective states are de facto 'uncoupled from governing', while a number of non-state orderings are fully engaged in governing significant spheres of activity. True, vast meaning should not be ascribed to trivialities like 'the law of queues' or 'the law of faculty meetings' - whatever their interest to sociologists but that does not exclude the possibility that non-state arrangements may lay serious claims to qualify as legal orders: they are impersonal; they intend to govern important aspects of social life, and to do so exclusively; and their potential to endure seems superior to that of a number of troubled states.

Whatever the reason for the expansion of arbitral and other non-state methods of resolving disputes, it seems futile to resist their claims to belong to the genus of legal processes. That some make excessive claims for pluralism does not deprive the concept of all force and value. To the contrary, there is solid ground at the centre; exaggerations may and should be ignored. What we need is a minimum of terminological discipline. Neil MacCormick was particularly clear in making the distinction between informal normative orders, which is not to be thought of as law, and formal institutional normative orders, which are. ${ }^{40}$ He used as a recurrent illustration the social phenomenon of queues, which of course is apt to evolve into part of an institutionalised order whenever it becomes subject to explicit authority. Specific implications of the categorisation may be given. For instance,

informal norms emerge from practices based on mutual expectations and beliefs, and any attempts to formulate in express terms the implicit norm depends on interpreting the practice and its point. Here, interpretation

37 Toward a New Common Sense: Law, Science and Politics in Paradigmatic Transition (London: Verso, 1995), 429.

38 'After Government? On Representing Law Without the State' (2005) 68 Modern Law Review 1.

39 ibid, 24.

40 N. MacCormick, The Institution of Law (Oxford: Oxford University Press, 2007), chs 1-2. (MacCormick nowhere mentions Romano.) 
precedes formulation. But in the case of rules explicitly issued, interpretation succeeds formulation. ${ }^{41}$

Just so, we find that the legal orders that comprise the fluid environment of the arbitral process must be one where interpretation follows formulation. This requires institution-building. Not all who claim to act institutionally can back it up. Some state orders cannot; some non-state orders can.

Yet private normative orderings cannot expect to survive long outside or below the radar of general constitutional order. They have not created a general system holding sway over an entire polity. There will be occasions, more or less frequent, when the private ordering asks for help, or finds itself making claims which the general constitutional order must notice and check if it is to maintain its own integrity and objectives. To take our subject: some arbitral awards would be illusory, and their very inefficacy apt to undermine the private ordering, unless the larger order may on occasion be enlisted to assist. On the other hand, some claims of autonomy of the private ordering would be perceived as threats to the legitimate role of the larger order unless they are rebuked and neutralised. This confirms that the pluralistic model, expanded to include non-state legal orders, must be conceived of as three-dimensional. The dimension of depth is required to account for the fact that legal orders in modern international society overlap, and therefore partially overlay each other. Arbitration will survive only if it adjusts to a type of dynamic tension akin to the force that propulses a catamaran as it knifes through roiling waters in a stiff breeze. If the crew is timorous, the vessel stalls; if they seek too much power, it capsizes. Just so, private orderings must be ambitious in order to be useful; but if they overreach, repudiation is likely to replace tolerance.

The three-dimensional conception developed here has implications for the daily conduct of actors in the arbitral process and for officials asked either to ensure or limit its effects. These implications would merit a lecture of their own, leaving the abstractions of the present study for more practical domains. Suffice it to observe here that an accurate perception of potentially overlapping legal orders should (i) make non-state institutions more confident in the struts of their authority, (ii) broaden the horizons and the culture of parties and arbitrators, and (iii) moderate the defensive illusions of exclusivity which still permeate certain state institutions. The prospect of participating in a universalist enterprise should engender a sense of community, exhilaration, and fulfilment, not self-denial.

${ }^{41}$ Coincidentally, the queue is precisely one of the phenomena - along with 'looking, staring and glaring' - subjected to sustained analysis by Michael Reisman in Law in Brief Encounters (New Haven: Yale University Press, 1999). Reisman took the matter of informal norms as far as one could, revealing it, one might say, as a form of sophisticated and instructive entertainment which could be replicated endlessly following - or refining and altering - his model. But there are sharply diminishing returns; good entertainment knows when to stop. 
Can we, in this fluid universe, find an organising principle to guide our appraisal of the social institution we call arbitration? Perhaps some such principle may have revealed itself to listeners in the course of this lecture, whether in agreement with or defiance to what you have heard. Perhaps a transcendent objective may itself play the role of an organising principle. This objective is fulfilment of the very idea of arbitration, which I define as follows: a binding resolution of disputes likely to be accepted with serenity by those who bear its consequences because of their special trust in a chosen decision-maker. If we take this aspiration as fundamental to the way we view, nurture, and indeed control arbitration, I suggest it also has a corollary. It is the following principle, conceived as a guide to other social institutions, such as courts and legislators, in their interaction with arbitrators: consensual arrangements for the resolution of disputes should be presumed valid; the value of freedom is so great that its curtailment cannot be justified by mere suppositions about its abuse.

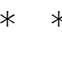

I saved an anecdote for last. 25 years ago, I had the terrifying experience of debating Francis Mann - just the two of us: no rules. ${ }^{42}$ The question to be debated was whether an award could have any effect once it had been rejected by the law of the place where it had been rendered. There was a surprisingly large crowd; I was unaware of the English appetite for blood sports. The verdict seemed unanimous. What I mean is that no one seemed to follow what I was saying. It will take some time for these people to see the light, I thought as I dolefully retreated homeward.

'If an award is annulled, it is nothing, and nothing can come from nothing,' say Mann's followers. I have persevered in a number of articles, ${ }^{43}$ pointing out that nothing stops country B from ignoring court A's judgment of annulment. If that judgment is nothing, the award stands. Ignoring a foreign court judgement is perhaps not a friendly thing to do, and one would not do so in the ordinary course, but it does happen. Nothing changes just because the judgment deals with an arbitral award. There is no conceptual impediment whatever - nor indeed, under either the New York Convention or the European Convention, a legal one.

Well, at long last, the English have begun to understand. I am referring again to the Dallah case, where Lord Justice Moore-Bick observed that a number of English cases had accepted that courts have a discretion to permit enforcement even in the presence of one of the grounds allowing refusal under the New York Convention, and noted that it might be necessary one day to consider whether

42 A full but unilateral account appears in J. Paulsson, 'Interference by National Courts', in Lawrence W. Newman and Richard D. Hill (eds), The Leading Arbitrators' Guide to International Arbitration (New York: Juris, 2nd ed, 2008), 119.

${ }^{43}$ See, eg, 'Enforcing Arbitral Awards Notwithstanding a Local Standard Annulment (LSA)' (1988) 9 ICC Court Bulletin 14 and other publications referred to therein. 
there might be circumstances under which enforcement of a foreign award might be allowed notwithstanding that the court at the seat of arbitration had set it aside. He did not say, as Mann would have said, that this is nonsense. Nor did he say that nothing can come from nothing. A good award is worthy of recognition; the 'nothingness', I repeat, may be that of an unworthy annulment decision. For debating purposes, you can guess my personal candidates for rejection: the setting aside of perfectly respectable awards in some unfortunate country for the sole reason that the tribunal included an atheist or a woman.

Now that is progress, and there is a bit more. Lord Justice May, in a case named Kanoria v Guinness (decided in 2006), ${ }^{44}$ made an interesting generic suggestion: that English courts were unlikely to allow enforcement if the 'structural integrity' of the arbitral proceedings were fundamentally unsound. $A$ contrario, one surmises, there is no impediment to disregarding formalistic or incomprehensible annulments of awards that meet all other criteria of soundness. And that would be more progress still.

${ }^{44}$ Kanoria v Guinness [2006] APP.L.R. 02/21. 